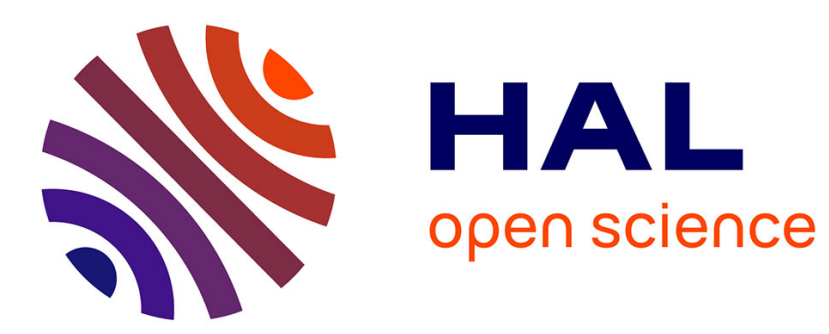

\title{
The electrochemical performance of melt-spun C14-Laves type TiZr-based alloy
}

Ika Dewi Wijayanti, Live Mølmen, Roman Denys, Jean Nei, Stéphane Gorsse, Kwo Young, Matylda Guzik, Volodymyr Yartys

\section{- To cite this version:}

Ika Dewi Wijayanti, Live Mølmen, Roman Denys, Jean Nei, Stéphane Gorsse, et al.. The electrochemical performance of melt-spun C14-Laves type TiZr-based alloy. International Journal of Hydrogen Energy, 2020, 45 (2), pp.527-537. 10.1016/j.ijhydene.2019.02.093 . hal-02435448

\section{HAL Id: hal-02435448 \\ https://hal.science/hal-02435448}

Submitted on 9 Jun 2020

HAL is a multi-disciplinary open access archive for the deposit and dissemination of scientific research documents, whether they are published or not. The documents may come from teaching and research institutions in France or abroad, or from public or private research centers.
L'archive ouverte pluridisciplinaire HAL, est destinée au dépôt et à la diffusion de documents scientifiques de niveau recherche, publiés ou non, émanant des établissements d'enseignement et de recherche français ou étrangers, des laboratoires publics ou privés. 


\title{
The electrochemical performance of melt-spun C14-Laves type Ti-Zr-based alloy
}

\author{
Ika Dewi Wijayanti ${ }^{a, b, c}$, Live Mølmen ${ }^{b}$, Roman V. Denys ${ }^{a}$, Jean Nei ${ }^{d}$, \\ Stéphane Gorsse ${ }^{e, f}$, Kwo Young ${ }^{d}$, Matylda N. Guzik ${ }^{g}$, \\ Volodymyr Yartys ${ }^{a, b, *}$ \\ a Department of Battery Technology, Institute for Energy Technology (IFE), Kjeller, Norway \\ ${ }^{\mathrm{b}}$ Department of Materials Science and Engineering, NTNU, Trondheim, Norway \\ c Department of Mechanical Engineering, Sepuluh Nopember Institute of Technology (ITS), Surabaya, Indonesia \\ d BASF/Battery Materials-Ovonic, Rochester Hills, USA \\ e CNRS, ICMCB, University of Bordeaux, UMR 5026, Pessac F 33600, France \\ ${ }^{\mathrm{f}}$ Bordeaux INP, ENSCBP, Pessac F 33600, France \\ ${ }^{g}$ Department of Physics, University of Oslo, Blindern, Oslo, Norway
}

\section{A R T I C L E I N F O}

Article history:

Received 9 November 2018

Received in revised form

9 February 2019

Accepted 12 February 2019

Available online 8 March 2019

\section{Keywords:}

Ti Zr based alloy

Metal hydride battery

Rapid solidification

Electrochemical performance

\begin{abstract}
A B S T R A C T
The main objective of the present work is to study the effect of rapid solidification on the electrochemical performance of $\mathrm{Zr}$ based Laves type alloy with a nominal composition $\mathrm{Ti}_{12} \mathrm{Zr}_{21.5} \mathrm{~V}_{10} \mathrm{Cr}_{7.5} \mathrm{Mn}_{8.1} \mathrm{Co}_{8} \mathrm{Ni}_{32.2} \mathrm{Al}_{0.4} \mathrm{Sn}_{0.3}$. The samples were prepared from the as cast arc melted buttons by melt spinning at different copper wheel rotation speeds of 5, 16.5, 33, and $100 \mathrm{~Hz}$, which are equivalent to linear speeds of $6.3,21,41$, and $62.8 \mathrm{~m} \mathrm{~s}{ }^{1}$ respectively using a cooling wheel with a diameter of $20 \mathrm{~cm}$. The phase composition and morphology of the ribbons were analyzed by X Ray diffraction (XRD) and scanning electron microscopy (SEM). The microstructural changes of the ribbons induced by the variations in the wheel rotation speed were found to be closely related to the electrochemical performances. High discharge capac ities exceeding $400 \mathrm{mAh} \cdot \mathrm{g}{ }^{1}$ were achieved for the melt spun samples during the measure ments at low current densities. Furthermore, melt spun casting performed at the highest wheel rotation speed of $100 \mathrm{~Hz}$ resulted in the best rate performance of the alloy. As this alloy has the smallest crystallite size, this resulted in the shortest $\mathrm{H}$ atoms diffusion distances, and thus increased the efficient $\mathrm{H}$ diffusion rate and improved the electrochemical performance. (C) 2019 Hydrogen Energy Publications LLC. Published by Elsevier Ltd. All rights reserved.
\end{abstract}

\section{Introduction}

$\mathrm{Zr}$ based Laves alloys have become the most promising can didates between the metal hydride (MH) alloys used as nega tive active electrode materials in the Nickel/Metal Hydride batteries due to their high capacities in storing hydrogen by forming $\mathrm{AB}_{2} \mathrm{H}_{3-4}$ hydrides [1-5]. However, poor activation performance of $\mathrm{AB}_{2} \mathrm{MH}$ alloys in comparison with that of the commercial $\mathrm{AB}_{5} \mathrm{MH}$ compositions motivated intensive studies to improve their electrochemical performance [6-8]. Rapid solidification (RS)/rapid quenching is one of the mate rials processing techniques which produces nanostructured alloys by applying cooling rates exceeding $10^{4} \mathrm{~K} \cdot \mathrm{s}^{1}$ to the molten metal, thus affecting both the phase composition and microstructure of the alloys [9-13]. Both the morphology and

\footnotetext{
* Corresponding author. Department of Battery Technology, Institute for Energy Technology (IFE), Kjeller, Norway.

E mail addresses: Ika.Dewi.Wijayanti@ife.no (I.D. Wijayanti), Volodymyr.Yartys@ife.no (V. Yartys).
} 
phase composition resulting from the rapid quenching pro cess can cause variations in the electrochemical performance [14-16]. Particularly, the kinetics of the processes occurring at the metal-electrolyte interface and the rate of hydrogen diffusion within the bulk alloy are changed $[17,18]$. Therefore, in order to improve the electrochemical performance, the optimized phase structures with fine morphology and an appropriate composition are highly desirable.

In the present study, RS process was performed on the $\mathrm{Ti}_{12} \mathrm{Zr}_{21.5} \mathrm{~V}_{10} \mathrm{Cr}_{7.5} \mathrm{Mn}_{8.1} \mathrm{Co}_{8} \mathrm{Ni}_{32.2} \mathrm{Al}_{0.4} \mathrm{Sn}_{0.3}$ alloy using different wheel rotation speed rates of $5,16.5,33$, and $100 \mathrm{~Hz}$. Additions of $\mathrm{Cu}$ [19], Fe [20], Zn [21], Si [22], Mo [23], B [24], and Pd [25] to this alloy were studied by BASF group in order to achieve improvements of the high rate dischargeability (HRD) perfor mances. These studies showed that HRD performance improved by adding $2 \mathrm{wt} \% \mathrm{Pd}$. By applying the rapid solidifi cation process, thus by achieving its nanostructuring $[26,27]$, we aim at improving the HRD performance of the alloy. Furthermore, the interrelation between the melt spinning rotation speed and the electrochemical properties of multi component $\mathrm{Zr}$ based Laves alloys and the corresponding charge discharge mechanism will be presented in this paper. The effects of the variation of the different cooling rates on the crystal structure, microstructure, phase abundance, and electrochemical properties of the rapidly solidified alloys will be reported.

\section{Experimental methods}

Alloy with the composition of $\mathrm{Ti}_{12} \mathrm{Zr}_{21.5} \mathrm{~V}_{10} \mathrm{Cr}_{7.5} \mathrm{Mn}_{8.1} \mathrm{Co}_{8}$ $\mathrm{Ni}_{32.2} \mathrm{Al}_{0.4} \mathrm{Sn}_{0.3}$ was prepared by induction melting under a protective atmosphere of helium gas by heating up the mixture of the raw materials placed into an $\mathrm{Al}_{2} \mathrm{O}_{3}$ crucible and holding the formed melt at $1500^{\circ} \mathrm{C}$ for $5 \mathrm{~min}$. The composition of the alloy was chosen because of its balanced performances in capacity, high rate dischargeability (HRD), charge reten tion, and cycle stability, and was previously used as the base material in other studies performed at BASF [24]. The as cast alloy was then used for the castings performed using a SC Edmund Buehler melt spinner accommodated at CNRS/Uni versity of Bordeaux (France) at wheel rotation speeds of 5, 16.5, 33 , or $100 \mathrm{~Hz}$.

The as cast alloy and four types of melt spun ribbons were mechanically crushed and ground to powder sizes of below $40 \mu \mathrm{m}$ and $40-60 \mu \mathrm{m}$ for the X Ray diffraction (XRD) and electrochemical measurements, respectively. XRD analysis was performed on a Bruker D8 Focus diffractometer using $\mathrm{Cu} \mathrm{K}_{\alpha}$ radiation in the $2 \theta$ angle range of $10-90^{\circ}$ and with a step size of $0.00157^{\circ}$ using a $1 \mathrm{~mm}$ slit. Rietveld re finements for the XRD pattern were carried out using the GSAS suite of programs [28] with the EXPGUI interface. A JEOL JSM6320F scanning electron microscope (SEM, Tokyo, Japan) equipped with energy dispersive spectroscopy (EDS) analysis was used to study the phases distribution and their composition.

MH pellet electrodes were prepared by first thoroughly mixing the alloy powder having a particle size of $40-60 \mu \mathrm{m}$ with carbonyl $\mathrm{Ni}$ powder with a specific surface area of $\sim 0.7 \mathrm{~m}^{2} \mathrm{~g}^{1}$ in the weight ratio of $1: 4$, which was then cold pressed under a pressure of $12 \mathrm{MPa}$ into a $10 \mathrm{~mm}$ diameter pellet which was then sandwiched between two Ni foams.

Electrochemical performance was measured using a CT 2001 Land Battery Tester with the three electrode system consisting of a $\mathrm{MH}$ alloy working electrode, a sintered $\mathrm{Ni}(\mathrm{OH})_{2} / \mathrm{NiOOH}$ counter electrode, and a $\mathrm{Hg} / \mathrm{HgO}$ reference electrode using a $9 \mathrm{M} \mathrm{KOH}$ aqueous solution as the electro lyte. Galvanostatic method was used to measure the activa tion and rate performance of $\mathrm{MH}$ electrode. $\mathrm{MH}$ electrode was charged at a current density of $100 \mathrm{~mA} \cdot \mathrm{g}{ }^{1}$ for $5 \mathrm{~h}$ followed by a $30 \mathrm{~min}$ rest and then discharged at a current density of $100 \mathrm{~mA} \cdot \mathrm{g}{ }^{1}$ to a voltage cut-off of $0.7 \mathrm{~V}$ against the $\mathrm{Hg} / \mathrm{HgO}$ reference electrode. After the $\mathrm{MH}$ electrode was fully acti vated, it was charged at a current density of $100 \mathrm{~mA} \cdot \mathrm{g}{ }^{1} \mathrm{fol}$ lowed by a $30 \mathrm{~min}$ rest and discharged at different current densities (0.1-1 C rate) to a voltage cut-off of $0.6 \mathrm{~V}$ against the $\mathrm{Hg} / \mathrm{HgO}$ reference electrode (see Table 1 presenting the details of the electrochemical characterisation experiments performed during the half cell measurements). The discharge rate performances of each sample are shown by calculating the ratio the discharge capacity at the highest current density to the capacity at the lowest current density [29].

\section{Results and discussion}

\section{Ribbon structure}

Morphologies of the ribbons appear to be directly related to the conditions of the Rapid Solidification performed at the University of Bordeaux/CNRS Bordeaux. With increasing wheel rotation speed, RS results in regular changes in width, length and thickness of the produced ribbons (see Fig. 1). Indeed, all dimensions of the ribbons gradually decrease when rotation frequency goes up from 5 to $100 \mathrm{~Hz}$. This is expected as thinner, shorter, and narrower ribbons are anticipated to be produced at higher rotation speeds. Dimensional parameters of the ribbons produced by melt spinning are shown in Table 2 .

\begin{tabular}{|c|c|c|c|c|}
\hline $\begin{array}{l}\text { Cycle } \\
\text { number }\end{array}$ & $\begin{array}{c}\text { Charge } \\
\text { current } \\
\left(\mathrm{mA} \cdot \mathrm{g}^{1}\right)\end{array}$ & $\begin{array}{l}\text { Charge } \\
\text { time (h) }\end{array}$ & $\begin{array}{c}\text { Discharge } \\
\text { current } \\
\left(\mathrm{mA} \cdot \mathrm{g}^{1}\right)\end{array}$ & $\begin{array}{c}\text { Discharge cut } \\
\text {-off voltage } \\
\text { (V) }\end{array}$ \\
\hline 133 & 100 & 5 & 100 & 0.7 \\
\hline 34 & 100 & 5 & 10 & 0.6 \\
\hline 35 & 100 & 5 & 34 & 0.6 \\
\hline 36 & 100 & 5 & 68 & 0.6 \\
\hline 37 & 100 & 5 & 100 & 0.6 \\
\hline 38 & 100 & 5 & 136 & 0.6 \\
\hline 39 & 100 & 5 & 169 & 0.6 \\
\hline 40 & 100 & 5 & 200 & 0.6 \\
\hline 41 & 100 & 5 & 237 & 0.6 \\
\hline 42 & 100 & 5 & 271 & 0.6 \\
\hline 43 & 100 & 5 & 305 & 0.6 \\
\hline
\end{tabular}




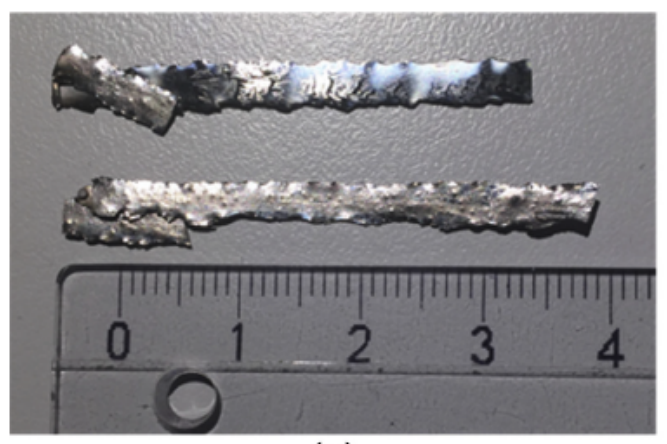

(a)

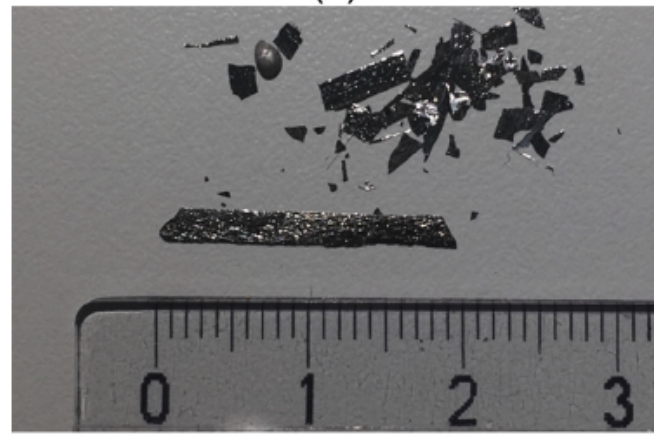

(c)

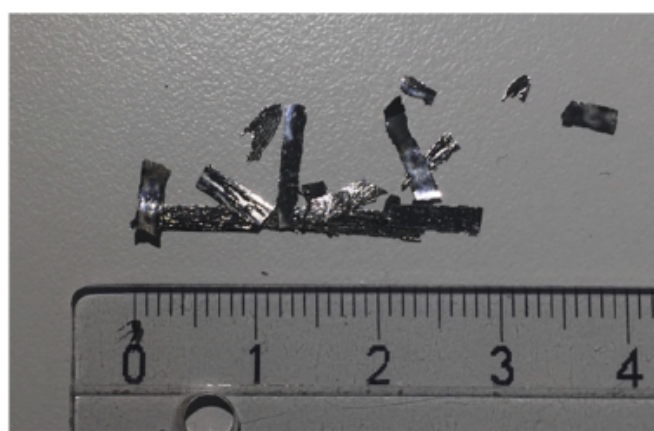

(b)

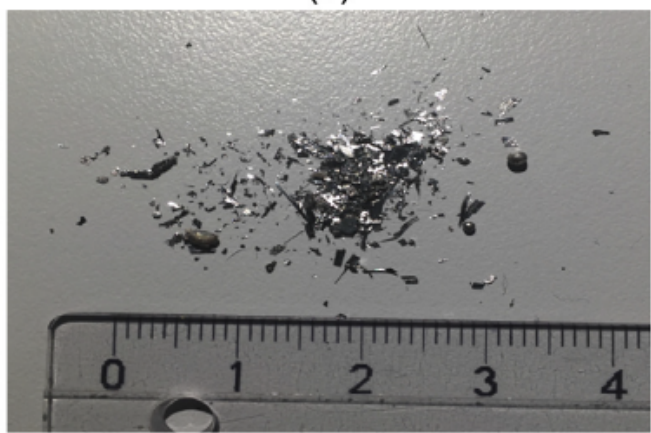

(d)

Fig. 1 - Ribbons produced using melt spinning at different wheel rotation speeds of 5 (a), 16.5 (b), 33 (c), and 100 (d) Hz. Higher solidification rates cause regular changes in width, length, and thickness of the produced ribbons which all gradually decreased when rotation frequency went up from 5 to $100 \mathrm{~Hz}$. Their values change from $0.5,4.4$, and $0.213 \mathrm{~mm}$ to $0.1,0.5$, and $0.043 \mathrm{~mm}$, respectively (see Table 2 for the details).

\section{XRD analysis}

XRD patterns of five studied alloys are shown in Fig. 2. All peaks can be fitted to a hexagonal Laves type C14 and a face centered cubic C15 Laves type structures. However, as the C14 phase is the main component with its abundancy exceeding $83 \mathrm{wt} \%$ for every studied material, in analysis of the crystallite size in GSAS refinements we only considered the related data as contributed by the main C14 phase only.

A typical Rietveld GSAS refinement plot for the as cast sample is presented in Fig. 3, while the data on the unit cell parameters, volumes of the unit cells, crystallite sizes, and phase abundances for the studied samples are given in Table 3. Two conclusions can be made when analyzing the data presented in this Table.

(a) As the wheel rotation speed increases, the abundance of the C14 phase becomes higher, suggesting that the C14 phase is more likely to form at higher solidification rates

Table $\mathbf{2}$ - Characteristics of the ribbons produced by melt spinning.

\begin{tabular}{lccc} 
Sample & Width $(\mathrm{mm})$ & Length $(\mathrm{mm})$ & Thickness $(\mathrm{mm})$ \\
\hline As cast & & & \\
$5 \mathrm{~Hz}$ & 0.5 & 4.4 & 0.213 \\
$16.5 \mathrm{~Hz}$ & 0.3 & 2.9 & 0.125 \\
$33 \mathrm{~Hz}$ & 0.2 & 2.0 & 0.057 \\
$100 \mathrm{~Hz}$ & 0.1 & 0.1 & 0.043 \\
\hline
\end{tabular}

as compared to the $\mathrm{C} 15$ phase. This is in agreement with an earlier report [30].

(b) For the C14 intermetallic the crystallite sizes gradually decrease from the initial $104 \mathrm{~nm}$ for the as cast alloy to $21 \mathrm{~nm}$ for the sample received by the melt spinning at $100 \mathrm{~Hz}$.

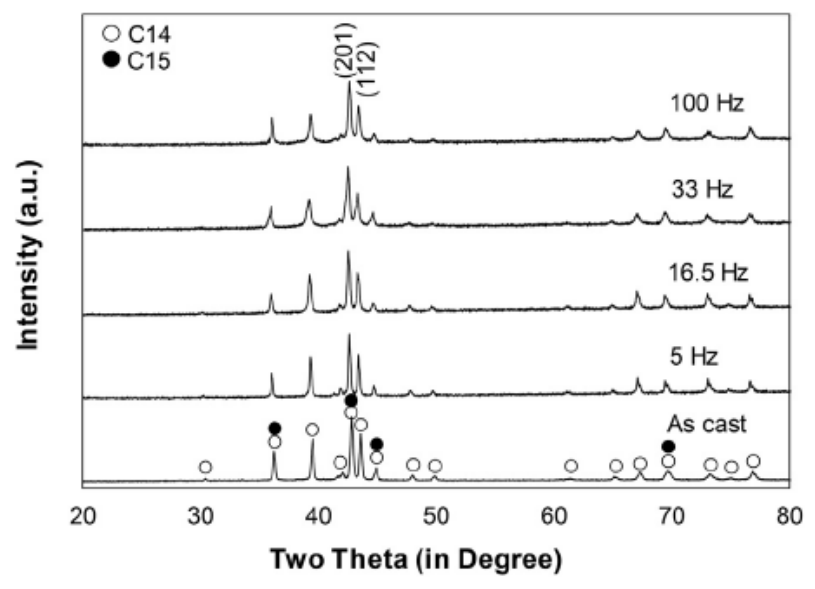

Fig. 2 - XRD patterns collected using $\mathrm{Cu}-\mathrm{K}_{\alpha}$ radiation for the as-cast and melt-spun samples with composition $\mathrm{Ti}_{0.20} \mathrm{Zr}_{0.80} \mathrm{La}_{0.01} \mathrm{Ni}_{1.2} \mathrm{Mn}_{0.70} \mathrm{~V}_{0.12} \mathrm{Fe}_{0.12}$ obtained at different wheel rotation speeds of $5,16.5,33$, and $100 \mathrm{~Hz}$. Two Laves phase intermetallics, C14 (major phase; $83.5 \mathrm{wt} \%$ ) and C15 (minor phase; $16.5 \mathrm{wt} \%$ ), were quantitatively identified. 


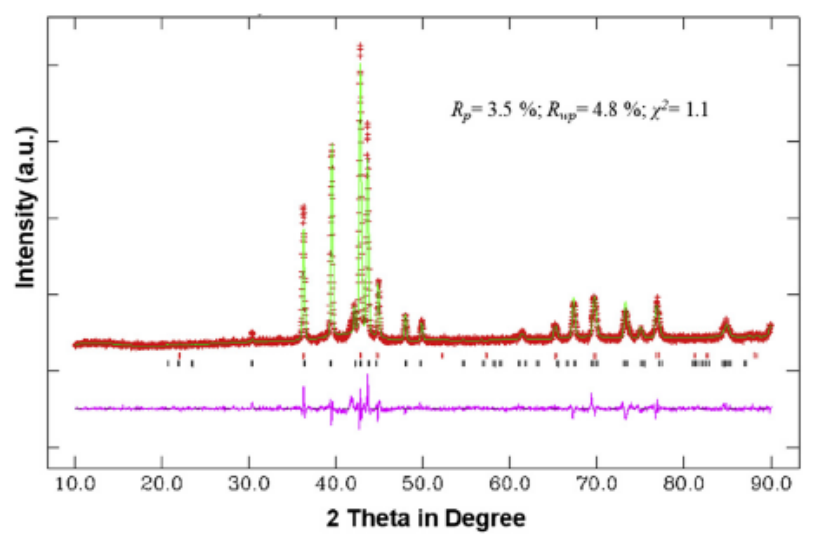

Fig. 3 - Observed (+), calculated (upper line), and difference (lower line) Rietveld GSAS refinement plots of the XRD pattern of the as-cast sample. The XRD data shows presence of two phases, C14 (83.5 wt\%; bottom ticks) and C15 (16.5 wt \%; top ticks) intermetallics. Reliability factors are: $\operatorname{Rp} \quad 3.5 \%$; Rwp $\quad 4.8 \%$; and $\chi^{2} \quad 1.1$.

As mentioned earlier, due to the small abundance of C15 phase, crystallite size for C15 phases has not been refined.

At the same time, unit cell parameters, c/a ratios and volumes of the unit cells show only slight variations $(1.3 \%$ in maximum for the volumes of the C14 Laves phase and $0.6 \%$ for the volumes of the $\mathrm{C} 15$ phase). These variations are probably related to the small changes in the stoichi ometry of the alloys introduced during the melt casting process.

\section{SEM/EDS analysis}

Microstructures of the alloys were studied by SEM, and their images collected in the backscattered electron (BSE) mode are presented in Fig. 4.

As cast sample shows a formation of the two phase microstructure containing C14 Laves type intermetallic as the main constituent and a secondary C15 intermetallic, with the main phase having a grain size with a length of appr. $15 \mu \mathrm{m}$ and a width of appr. 3-5 $\mu \mathrm{m}$ (see Fig. 4).

Casting by rapid solidification significantly and regularly changes the phase composition and morphology of the con stituents because of the increasing solidification rate being proportional to the increasing wheel rotation speed.
Rapid solidification causes the following changes

(a) Grain size significantly and gradually decreases with increasing the wheel rotation speed. Indeed, already at a rotation speed of $5 \mathrm{~Hz}$ the grain size drops from the initial $15 \mu \mathrm{m}$ to just approximately $2 \mu \mathrm{m}$ at $5 \mathrm{~Hz}$ and further down to $900 \mathrm{~nm}$ at $100 \mathrm{~Hz}$.

(b) Increased rate of RS causes formation of a dendrite microstructure. Dendrites appear in the samples casted at $16.5 \mathrm{~Hz}$ and at $33 \mathrm{~Hz}$. The size $(3 \rightarrow 2 \mu \mathrm{m})$ and arm spacing $(250 \rightarrow 200 \mathrm{~nm})$ of the dendritic structure de creases with increasing solidification rate $(16.5 \rightarrow 33 \mathrm{~Hz})$.

(c) Finally, at $100 \mathrm{~Hz}$ rotation speed, the morphology be comes more uniform with a matrix C14 phase composing a core and a secondary $\mathrm{C} 15$ phase forming a shell. Large number of nuclei of the main C14 phase is formed in the RS samples due to the higher melting temperature of this intermetallic. When the rotation speed increases, these nuclei do not have enough time to grow and these limitations in the kinetics of growth result is a smaller dendrite sizes and arm spacings. When reaching the highest solidification rate, the ma trix and secondary phase compete with each other to firstly nucleate while not always having a sufficient time to grow. By increasing the rotation speed to $100 \mathrm{~Hz}$, a homogeneous structure with a more even distribution of secondary phase in the structure is formed while the dendrite structure is no longer observed.

\section{Electrochemical measurements}

As shown in Fig. 5, the as cast alloy has the best activation performance among all studied alloys, requining approxi mately 10 activation cycles to reach the discharge capacity of close to $280 \mathrm{~mA} \cdot \mathrm{g}^{1}$. All melt spun alloys need more than 15 cycles to be activated, even up to 17 to 20 cycles for a $16.5 \mathrm{~Hz}$ speed (Fig. 5 (a)). We assume that the RS process increased the thickness of the native oxide on the $\mathrm{MH}$ alloy surface which required extra cycles of charge discharge to be removed. The increase in the C14 phase abundance and a larger amount of the surface oxides in the starting $5 \mathrm{~Hz}$ RS alloy caused a more difficult activation of the sample. Similar difficulties in acti vation were observed for other RS materials. Thirty three cy cles were performed for all the melt spun alloys to ensure that the $\mathrm{MH}$ electrodes were fully activated and ready for the discharge rate measurements. Among all the melt spun al loys, $100 \mathrm{~Hz}$ melt spun alloy showed the fastest activation and

Table 3 - Crystallographic data, crystallite size and phase abundances for the as-cast and melt-spun samples from the Rietveld GSAS refinements.

\begin{tabular}{|c|c|c|c|c|c|c|c|c|c|}
\hline \multicolumn{7}{|l|}{ C14 } & \multicolumn{3}{|c|}{$\mathrm{C} 15$} \\
\hline Alloy & $a, \AA$ & $c, \AA$ & $c / a$ & $\mathrm{~V}, \AA^{3}$ & Crystallite size, $\mathrm{nm}$ & Abundance, wt.\% & $a, \AA$ & $\mathrm{V}, \AA^{3}$ & Abundance wt.\% \\
\hline As cast & $4.9662(1)$ & $8.0935(2)$ & 1.6297 & $172.9(1)$ & 104 & $83.5(4)$ & $7.0037(3)$ & $343.5(4)$ & $16.5(1)$ \\
\hline $5 \mathrm{~Hz}$ & $4.9454(2)$ & $8.0587(3)$ & 1.6295 & $170.7(1)$ & 29 & $89.3(4)$ & $6.9888(1)$ & $341.3(2)$ & $10.7(4)$ \\
\hline $16.5 \mathrm{~Hz}$ & $4.9594(2)$ & $8.0800(5)$ & 1.6292 & $172.1(2)$ & 26 & $94.3(3)$ & 7.0106 (6) & 344.6 (9) & $5.7(3)$ \\
\hline $33 \mathrm{~Hz}$ & $4.9563(4)$ & $8.0761(8)$ & 1.6294 & $171.8(4)$ & 21 & $84.6(8)$ & $6.9945(6)$ & $342.2(9)$ & $15.4(2)$ \\
\hline $100 \mathrm{~Hz}$ & $4.9660(4)$ & $8.0906(8)$ & 1.6291 & $172.8(4)$ & 21 & 83.8 (1) & 7.0173 (6) & 345.5 (9) & $16.2(3)$ \\
\hline
\end{tabular}




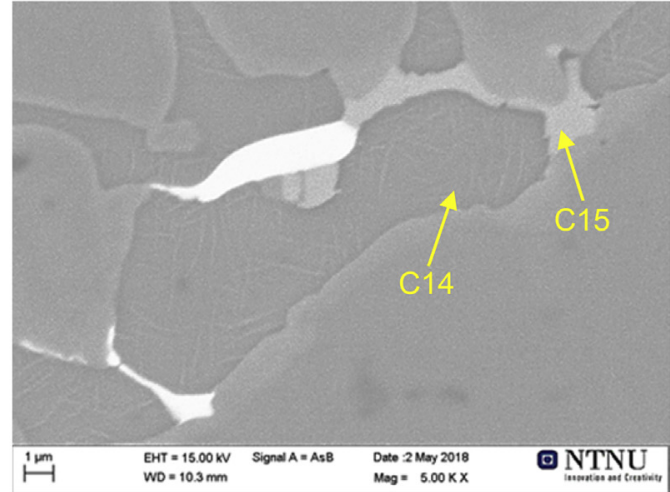

(a)

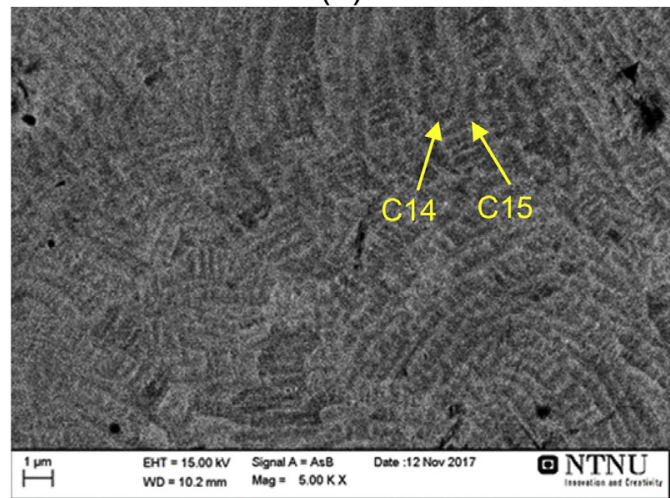

(c)

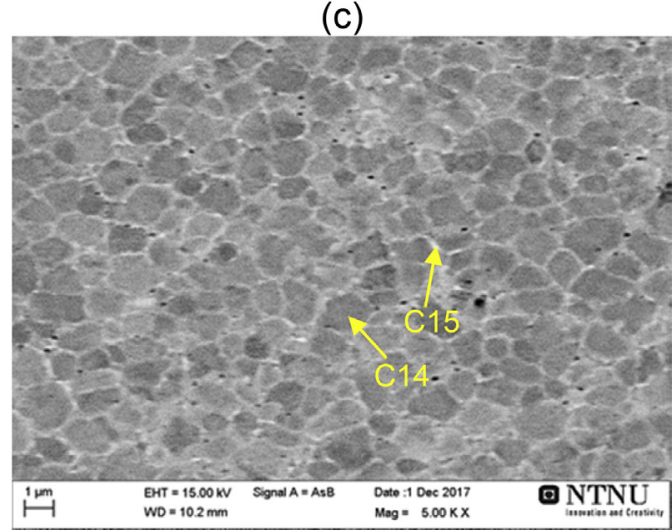

(e)

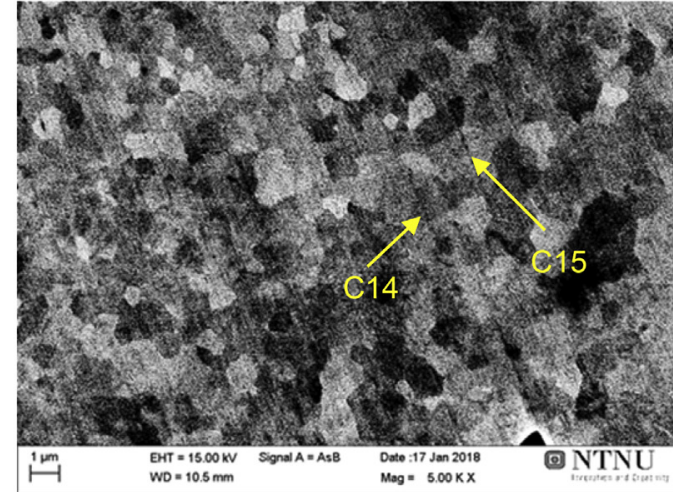

(b)

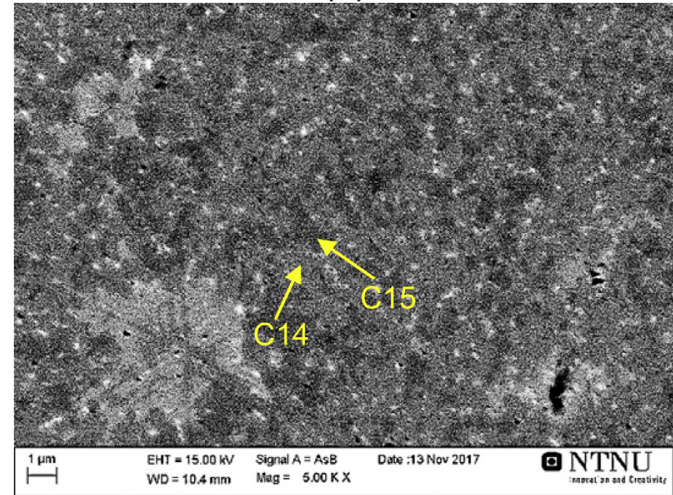

(d)

Fig. 4 - BSE SEM micrographs of as-cast (a) and melt-spun samples produced at different rotation speeds of $5 \mathrm{~Hz}$ (b), $16.5 \mathrm{~Hz}$ (c), $33 \mathrm{~Hz}(\mathrm{~d})$, and $100 \mathrm{~Hz}(\mathrm{e})$.

the highest discharge capacity (after 33 charge discharge cy cles) of $237 \mathrm{mAh} \cdot \mathrm{g}^{1}$. This can be due to its optimized microstructure showing a significant refinement, and a rather limited phase segregation as compared to the other melt spun samples.

The discharge rate performances of each sample are pre sented in Fig. 5 (b). These rate performances were evaluated by calculating high rate dischargeability (HRD) given in Table 4, which presents the ratio of the discharge capacity available at the highest current density of $304 \mathrm{~mA} \mathrm{~g}^{1}$ to the electro chemical capacity at the lowest current density at $10 \mathrm{~mA} \mathrm{~g}{ }^{1}$. The as cast alloy shows the highest discharge capacity at most applied discharge current densities. The highest discharge capacity at the lowest current density measurement is observed for the melt spun $16.5 \mathrm{~Hz}$ sample. This capacity drops faster during the initial increase in current densities, but the decrease in capacity slows down as the current density increases further indicating that the RS pro cess effectively improves the rate performance at higher current densities. Gradual capacity decrease for the studied alloys with increasing current densities can be observed clearer by analyzing the data of the Table 4. The largest decrease in HRD is found to happen for a $16.5 \mathrm{~Hz}$ sample, then followed by $33 \mathrm{~Hz}$ and $5 \mathrm{~Hz}$ samples. However, this rapid decrease only takes place at lower current densities. As cast sample shows the smallest decrease in the capacity at the beginning, but it becomes more pronounced when the current density increases. 


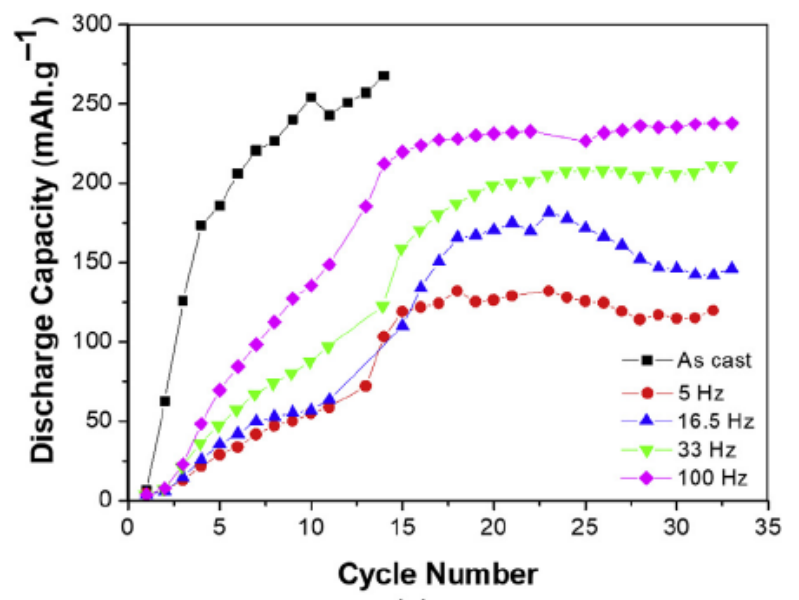

(a)

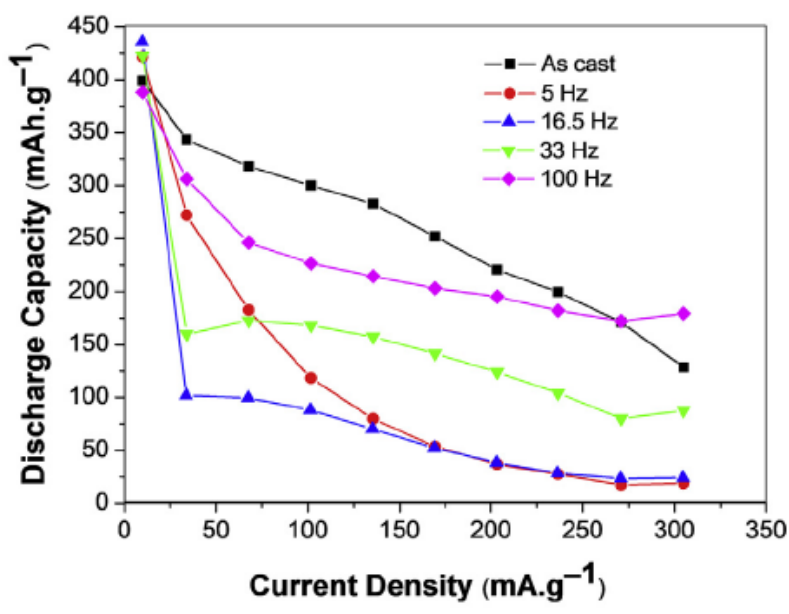

(b)

Fig. 5 - Electrochemical activation on cycling (a) and rate dependence of discharge capacity (b) of the alloys studied in this work. The activation becomes more difficult for the melt-spun samples; however, the best rate performance is achieved at the highest rotation speed of $100 \mathrm{~Hz}$, as can be concluded from its lowest slope.

We observe evidences that different quenching rates ach ieved due to the variation of the wheel rotation speed of the melt spinner result in microstructural changes in the alloy

Table 4 - HRD characteristics of the as-cast and meltspun samples (\%).

\begin{tabular}{llllll}
$\begin{array}{l}\text { Current density } \\
\left(\mathrm{mA}^{\mathrm{1}}{ }^{\text {) }}\right.\end{array}$ & $\begin{array}{l}\text { As } \\
\text { cast }\end{array}$ & $5 \mathrm{~Hz}$ & $16.5 \mathrm{~Hz} 33 \mathrm{~Hz} 100 \mathrm{~Hz}$ \\
\hline 10 & 100 & 100 & 100 & 100 & 100 \\
34 & 86 & 64 & 23 & 38 & 79 \\
68 & 80 & 43 & 23 & 41 & 63 \\
100 & 75 & 28 & 20 & 40 & 58 \\
136 & 71 & 19 & 16 & 37 & 55 \\
169 & 63 & 13 & 12 & 33 & 52 \\
200 & 55 & 9 & 9 & 29 & 50 \\
237 & 50 & 6 & 7 & 25 & 47 \\
271 & 43 & 4 & 5 & 19 & 44 \\
304 & 32 & 4 & 6 & 21 & 46 \\
\hline
\end{tabular}

which significantly affect the electrochemical performance. Further to the microstructural modifications, the abundance of the $\mathrm{C} 14$ and $\mathrm{C} 15$ phases also changes as a result of rapid so lidification. The ratio C14/C15 plays an important role in elec trode performance as C14 phase is favourable for achieving high electrochemical capacity while C15 phase causes high rate performance of the electrode. With increasing the rotation speed, the higher solidification rates are achieved which re sults in reduced grain sizes of the processed alloy. Lower so lidification rates resulting from application of lower wheel rotation speeds (16.5 and $33 \mathrm{~Hz}$ ) cause formation of dendritic structures and such morphology slows down hydrogen diffu sion thus causing inferior rate performance of the battery an odes. Not only slowing down of the hydrogen diffusivity but also a decrease in the surface exchange currents for the den dritic structures were reported earlier in the reference data [31] and were linked to the inferior rate performance of the metal hydride anodes. Thus, forming a homogeneous nano structured metal hydride anode with an optimised ratio C14/ C15 which was achieved for the highest applied solidification rate will allow reaching the best electrochemical performance.

The best HRD performance is observed for the $100 \mathrm{~Hz}$ sample which is showing only a small drop in the discharge capacity at each step of ramping up of the applied current density during the HRD experiments. This is probably caused by the smallest crystallite sizes observed for this sample resulting in the fastest hydrogen diffusion in the bulk material.

The slight compositional variations and phase structural changes induced by RS process affect the activation and rate performances. The most abundant C14 phase which is less prone to pulverization with smaller amount of the C15 phase present in the melt spun alloy (which undergoes hydride decrepitation faster and more easily) correlates with the poorer activation performance of the $\mathrm{C} 14$ predominant alloys. The surface of these alloys should be activated to reach their maximum electrochemical capacity, and a treatment in hot $\left(80^{\circ} \mathrm{C}\right) \mathrm{KOH}$ solution is one of the possible options to try. On the other hand, the optimized structure obtained by reaching an appropriate ratio between $\mathrm{C} 14$ and $\mathrm{C} 15$ phases provides a synergetic effect and improves the rate performance. More over, RS process proved to cause a pronounced refinement of the microstructures thus reducing the distance for the hydrogen diffusion and creating a faster hydrogen diffusion paths through the alloy.

\section{Conclusions}

The effect of cooling rate variation during the melt casting of the $\mathrm{Ti}_{12} \mathrm{Zr}_{21.5} \mathrm{~V}_{10} \mathrm{Cr}_{7.5} \mathrm{Mn}_{8.1} \mathrm{Co}_{8} \mathrm{Ni}_{32.2} \mathrm{Al}_{0.4} \mathrm{Sn}_{0.3}$ alloy has been studied. All melt spun samples showed a predominant for mation of the C14 Laves type intermetallic phase. Rapid solid ification process significantly affects the morphology and microstructure of the alloys. Equiaxed grain structure is formed at a lower rotation speed, while the dendritic structures solidify at higher rotation speeds, and finally the dendritic structure vanished and equiaxed grains with the phase segregation at the grain boundaries are observed at the highest rotation speed. The discharge rate performances improved with the rapid so lidification process and were the best at the highest applied 
cooling rate achieved at $100 \mathrm{~Hz}$. This phenomenon is believed to be due to the optimized structure obtained by reaching an appropriate ratio between C14 and C15 phases providing a synergetic effect and improving the rate performance.

\section{Acknowledgement}

This work was supported by Norwegian Research Center on Zero Emission Energy Systems for Transport (MoZEES). We thank CNRS/University of Bordeaux and Prof. Jean Louis Bobet for the availability of the laboratory facilities for the rapid solidification process, and BASF Ovonic Rochester Hills, USA for the access to their research laboratories during the work on this project. Ika Dewi Wijayanti received a fellowship from Indonesia Endowment fund for Education (LPDP) to perform a $\mathrm{PhD}$ research project at NTNU/IFE in Norway.

\section{R E F E R E N C E S}

[1] Yartys V, Noreus D, Latroche M. Metal hydrides as negative electrode materials for NiMH batteries. Appl Phys A 2016;122:43.

[2] Young K H, Nei J, Wan C, Denys R, Yartys V. Comparison of C14 and C15 predomiated $\mathrm{AB}_{2}$ metal hydride alloys for electrochemical applications. Batteries 2017;3:22.

[3] Young K H, Koch JM, Wan C, Denys RV, Yartys VA. Cell performance comparison between C14 and C15 predomiated $\mathrm{AB}_{2}$ metal hydride alloys. Batteries 2017;3:29.

[4] Young K H, Nei J. The current status of hydrogen storage alloy development for electrochemical applications. Materials 2013;6:4574 608.

[5] Fetcenko MA, Ovshinsky SR, Reichman B, Young K, Fierro C, Koch J, et al. Recent advances in NiMH battery technology. J Power Sources 2007;165:544 51.

[6] Tan S, Shen Y, Onur Șahin E, Noréus D, Öztürk T. Activation behavior of an $\mathrm{AB}_{2}$ type metal hydride alloy for $\mathrm{NiMH}$ batteries. Int J Hydrog Energy 2016;41:9948 53.

[7] Miao H, Gao M, Liu Y, Lin Y, Wang J, Pan H. Microstructure and electrochemical properties of $\mathrm{Ti} \mathrm{V}$ based multiphase hydrogen storage electrode alloys $\mathrm{Ti}_{0.8} \mathrm{Zr}_{0.2} \mathrm{~V}_{2.7} \mathrm{Mn}_{0.5} \mathrm{Cr}_{0.8}$ ${ }_{x} \mathrm{Ni}_{1.25} \mathrm{Fe}_{\mathrm{x}}(\mathrm{x}=0.0$ 0.8). Int J Hydrog Energy 2007;32:3947 53.

[8] Liu Y, Pan H, Gao M, Wang Q. Advanced hydrogen storage alloys for $\mathrm{Ni} / \mathrm{MH}$ rechargeable batteries. J Mater Chem 2011;21:4743 55.

[9] Suwarno S, Solberg JK, Maehlen JP, Krogh B, Børresen BT, Ochoa Fernandez E, et al. Microstructure and hydrogen storage properties of as cast and rapidly solidified Ti rich Ti V alloys. Trans Nonferrous Metals Soc China 2012;22:1831 8

[10] Wu Y, Lototsky MV, Solberg JK, Yartys VA. Microstructural evolution and improved hydrogenation dehydrogenation kinetics of nanostructured melt spun $\mathrm{Mg} \mathrm{Ni}$ Mm alloys. J Alloy Comp 2011;509:S640 5.

[11] Wu Y, Han W, Zhou SX, Lototsky MV, Solberg JK, Yartys VA. Microstructure and hydrogenation behavior of ball milled and melt spun $\mathrm{Mg}$ 10Ni 2Mm alloys. J Alloy Comp 2008;466:176 81.

[12] Wu Y, Solberg JK, Yartys VA. The effect of solidification rate on microstructural evolution of a melt spun $\mathrm{Mg} 20 \mathrm{Ni} 8 \mathrm{Mm}$ hydrogen storage alloy. J Alloy Comp 2007;446 447:178 82.

[13] Nwakwuo CC, Holm T, Denys RV, Hu W, Maehlen JP, Solberg JK, et al. Effect of magnesium content and quenching rate on the phase structure and composition of rapidly solidified $\mathrm{La}_{2} \mathrm{MgNi}_{9}$ metal hydride battery electrode alloy. J Alloy Comp 2013;555:201 8.

[14] Zhang Y, Shang H, Li Y, Hou Z, Qi Y, Guo S. Structure and electrochemical hydrogen storage behaviors of RE Mg Ni Co Al based $\mathrm{AB}_{2}$ type alloys prepared by melt spinning. J Alloy Comp 2017;699:378 85.

[15] Zhang Y, Ren H, Li B, Guo S, Pang Z, Wang X. Electrochemical hydrogen storage characteristics of nanocrystalline and amorphous $\mathrm{Mg}_{20} \mathrm{Ni}_{10-\mathrm{x}} \mathrm{Co}_{\mathrm{x}}(\mathrm{x}=0$ 4) alloys prepared by melt spinning. Int J Hydrog Energy 2009;34:8144 51.

[16] Zhang Y, Cai Y, Zhao C, Zhai T, Zhang G, Zhao D. Electrochemical performances of the as melt $\mathrm{La}_{0.75}{ }_{\mathrm{x}} \mathrm{M}_{\mathrm{x}} \mathrm{Mg}_{0.25} \mathrm{Ni}_{3.2} \mathrm{Co}_{0.2} \mathrm{Al}_{0.1}(\mathrm{M}=\mathrm{Pr}, \mathrm{Zr} ; \mathrm{x}=0,0.2)$ alloys applied to $\mathrm{Ni} / \mathrm{metal}$ hydride (MH) battery. Int J Hydrog Energy 2012;37:14590 7.

[17] Zhang SK, Shu KY, Lei YQ, Lü GL, Wang QD. Effect of solidification rate on the phase structure and electrochemical properties of alloy $\mathrm{Zr}_{0.7} \mathrm{Ti}_{0.3}(\mathrm{MnVNi})_{2}$. J Alloy Comp 2003;352:158 62.

[18] Zhang Y, Li B, Ren H, Wu Z, Dong X, Wang X. Investigation on structures and electrochemical characteristics of the as cast and quenched $\mathrm{La}_{0.5} \mathrm{Ce}_{0.2} \mathrm{Mg}_{0.3} \mathrm{Co}_{0.4} \mathrm{Ni}_{2.6}{ }_{\mathrm{x}} \mathrm{Mn}_{\mathrm{x}}(\mathrm{x}=0$ 0.4) electrode alloys. J Alloy Comp 2008;461:591 7.

[19] Young K H, Ouchi T, Huang B, Reichman B, Fetcenko MA. Studies of copper as a modifier in C14 predominant $\mathrm{AB}_{2}$ metal hydride alloys. J Power Sources 2012;204:205 12.

[20] Young K H, Ouchi T, Huang B, Reichman B, Fetcenko MA. The structure, hydrogen storage, and electrochemical properties of Fe doped $C 14$ predominating $\mathrm{AB}_{2}$ metal hydride alloys. Int J Hydrog Energy 2011;36:12296 304.

[21] Young K, Ouchi T, Lin X, Reichman B. Effects of $Z n$ addition to C14 metal hydride alloys and comparisons to Si, Fe, Cu, Y, and Mo additives. J Alloy Comp 2016;655:50 9.

[22] Young K H, Ouchi T, Huang B, Reichman B, Blankenship R. Improvement in $40 \mathrm{C}$ electrochemical properties of $\mathrm{AB}_{2}$ metal hydride alloy by silicon incorporation. J Alloy Comp 2013;575:65 72.

[23] Young K H, Ouchi T, Huang B, Reichman B, Fetcenko MA. Effect of molybdenum content on structural, gaseous storage, and electrochemical properties of C14 predominant $\mathrm{AB}_{2}$ metal hydride alloys. J Power Sources 2011;196:8815 21.

[24] Chang S, Young K H, Ouchi T, Nei J, Wu X. Effects of Boron incorporation in a $\mathrm{V}$ containing $\mathrm{Zr}$ based $\mathrm{AB}_{2}$ metal hydride alloy. Batteries 2017;3:36.

[25] Young K H, Ouchi T, Nei J, Chang S. Increase in the surface catalytic ability by addition of Palladium in C14 metal hydride alloy. Batteries 2017;3:26.

[26] Zhang Y, Zhao C, Yang T, Shang H, Xu C, Zhao D. Comparative study of electrochemical performances of the as melt $\mathrm{Mg}_{20} \mathrm{Ni}_{10}{ }_{\mathrm{x}} \mathrm{M}_{\mathrm{x}}(\mathrm{M}=\mathrm{None}, \mathrm{Cu}, \mathrm{Co}, \mathrm{Mn} ; \mathrm{x}=0,4)$ alloys applied to Ni/metal hydride (MH) battery. J Alloy Comp 2013;555:131 7.

[27] Zhang Y, Liu Z, Li B, Ma Z, Guo S, Wang X. Structure and electrochemical performances of $\mathrm{Mg}_{2} \mathrm{Ni}_{1}{ }_{\mathrm{x}} \mathrm{Mn}_{\mathrm{x}}(\mathrm{x}=0 \quad 0.4)$ electrode alloys prepared by melt spinning. Electrochim Acta 2010;56:427 34.

[28] Larson AC, Von Dreele RB. General structure analysis system (GSAS), Los Alamos national laboratory report LAUR 86 748. 2004.

[29] Young K, Ouchi T, Liu Y, Reichman B, Mays W, Fetcenko M. Structural and electrochemical properties of $\mathrm{Ti}_{\mathrm{x}} \mathrm{Zr}_{7}{ }_{\mathrm{x}} \mathrm{Ni}_{10}$. J Alloy Comp 2009;480:521 8.

[30] Stein F, Palm M, Sauthoff G. Structure and stability of Laves phases part II structure type variations in binary and ternary systems. Intermetallics 2005;13:1056 74 .

[31] Young K, Young M, Ouchi T, Reichman B, Fetcenko MA. Improvement in high rate dischargeability, activation, and low temperature performance in multi phase $\mathrm{AB}_{2}$ alloys by partial substitution of $\mathrm{Zr}$ with Y. J Power Sources 2012;215:279 87. 